\title{
UWAGI DOTYCZACCE KAMPANII MOŁDAWSKIEJ MIKOŁAJA KAMIENIECKIEGO W 1509 ROKU
}

\begin{abstract}
Streszczenie. Kampania mołdawska Mikołaja Kamienieckiego z 1509 r. jest stosunkowo mało znana i niewielu historyków poświęcało jej większą uwagę. Celem pracy jest przedstawienie wyników analizy źródeł, dotyczących czasu trwania kampanii, trasy przemarszu wojsk polskich oraz szerszego wymiaru międzynarodowego samej wyprawy Mikołaja Kamienieckiego. Dostępne źródła pozwalają przedstawić nowe fakty dotyczące tych wydarzeń i zaproponować odmienne od dotychczasowych wnioski.
\end{abstract}

Słowa kluczowe: Bogdan III Orbul, Zygmunt I Stary, hospodarstwo mołdawskie, wojna polsko-mołdawska 1509 r., Mikołaj Kamieniecki.

K ampania mołdawska Mikołaja Kamienieckiego z roku 1509 r. była jednym z epizodów szerszego konfliktu polsko-mołdawskiego, któJagiellonką oraz konflikt o Pokucie. Wojna wpisywała się w serię starć między obydwoma państwami, które trwały niemal od początku XV w. Dokładny przebieg tego konfliktu nie jest przedmiotem tej pracy, dlatego też zostanie on przedstawiony tylko w zarysie, koniecznym dla zrozumienia poruszonych problemów. Podstawowymi źródłami, które mówią o tych wydarzeniach są kroniki: Ludwika Decjusza, Macieja Stryjkowskiego, Bernarda Wapowskiego, Marcina Bielskiego ${ }^{1}$. Do tej pory nie wykorzystywano jednak mołdawskiej

${ }^{1}$ M. Bielski, Kronika Polska Marcina Bielskiego, cz. 5, t. XVI, Warszawa 1830; Decjusz, Księga o czasach króla Zygmunta, Warszawa 1960; M. Stryjkowski, Kronika polska, litewska, żmudzka i wszystkiej Rusi Macieja Stryjkowskiego, Warszawa 1846; B. Wapowski, Kronika Bernarda Wapowskiego z Radochoniec kantora katedr. krakowskiego: część ostatnia czasy podługoszowskie obejmująca (1480-1535), Kraków 1874. 
kroniki Urechiego ${ }^{2}$, która wprowadza pewne nowe informacje, dlatego starałem się je uwzględnić.

Historycy poświęcili niewiele miejsca tej kampanii. Najbardziej rozbudowaną pracą jest artykuł Kazimierza Pułaskiego pt. Wojna Zygmunta I. $z$ Bohdanem wojewodq mołdawskim $w 1509^{3}$. Publikacja ta jednak pochodzi z 1887 r. i posiada kilka nieścisłości. Należy również zauważyć, że odnosi się ona do całego konfliktu i niewiele miejsca poświęca samym działaniom wojennym. Inni historycy zajmowali się tą kampanią tylko w kontekście szerszych zagadnień, takich jak ogólne stosunki polsko-mołdawskie w tym okresie. Należy tutaj przytoczyć takie prace jak: Wojny i wojskowość polska w XVI wieku: lata 1500-1548 Marka Plewczyńskiego oraz Awantury mołdawskie Zdzisława Spieralskiego ${ }^{4}$. Osobiście również zajmowałem się tym tematem ${ }^{5}$, jednak wciąż nie został on opracowany w sposób wyczerpujący.

Konflikt z Mołdawią został zapoczątkowany przez najazd hospodara Bogdana III na Pokucie i Podole, w czerwcu 1509 r. Najeźdźcy dopuścili się wtedy wielkich grabieży i okrucieństw. Wojska mołdawskie po zajęciu Pokucia, próbowały opanować najważniejsze miasta na Podolu. Hospodar oblegał bezskutecznie Kamieniec Podolski, Lwów i Halicz. Dopiero koncentracja wojsk królewskich pod Lwowem (w lipcu i sierpniu 1509 r.) zmusiła go do wycofania się do Mołdawii. Armię polską prowadzić miał sam król Zygmunt I Stary, jednak z powodu nagłego ataku febry musiał przekazać naczelne dowództwo hetmanowi Mikołajowi Kamienieckiemu. Ten doświadczony wódz poprowadził oddziały polskie do Mołdawii. Dopuszczając się wielu odwetowych grabieży i mordów, dotarł pod Suczawę i stamtąd zaczął cofać się w granice Królestwa Polskiego. Podczas przeprawy pod Chocimiem, kiedy oddziały Kamienieckiego były rozdzielone Dniestrem (pospolite ruszenie już było na północnym brzegu), pojawiły się wojska mołdawskie. W rozegranej bitwie Mikołaj Kamieniecki odniósł wielkie zwycięstwo i wziął wielu znacznych jeńców. Wiadomo, że starcie odbyło się 4 października w święto św. Franciszka i było ostatnim etapem wyprawy z $1509 \mathrm{r}$.

${ }^{2}$ G. Ureche, Letopisetul Tarii Moldavei de cand sau descalecat tara, Tom I, https://archive. org/details/LetopisetulTariiMoldoveiDeCandS-auDescalecatTara/page/n123/mode/2up, (dostęp: 18.12.2019).

${ }^{3}$ K. Pułaski, Wojna Zygmunta I. z Bogdanem wojewoda mołdawskim w 1509, [w:] Szkice i poszukiwania historyczne, Kraków 1887.

${ }^{4}$ M. Plewczyński, Wojny i wojskowość polska w XVI wieku: lata 1500-1548, Zabrze 2011; Z. Spieralski, Awantury mołdawskie, Warszawa 1967.

${ }^{5}$ K. Gryglewski, Polskie wyprawy zbrojne na Mołdawię w latach 1497, 1509, 1531. Analiza porównawcza, Łódź 2019. Praca licencjacka napisana pod kierunkiem prof. nadzw. dr. hab. Tadeusza Grabarczyka, w Katedrze Historii Średniowiecznej, na Wydziale Historyczno-Filozoficznym UŁ. 
Kluczowym problemem z perspektywy zrozumienia całej kampanii w 1509 r. jest czas jej. W przekazach kronikarskich możemy znaleźć jedynie dwa odniesienia do tego problemu. Pierwszym jest wspomniana data bitwy nad Dniestrem. Drugim ogólne stwierdzenie, że hetman grabił terytorium mołdawskie przez 20 dni $^{6}$. Podkreślić w tym miejscu należy słowa Bernarda Wapowskiego: „Redibat pervasta Moldavia regius exercitus, praeda onustus vicesima die, ab eo quo primum Poloni Valachiam sunt ingressi" ${ }^{7}$. Na podstawie tego zdania widać, że kronikarz podaje owe 20 dni, licząc od wkroczenia wojsk polskich do Mołdawii. Na tej podstawie można postawić tezę, że wojska Mikołaja Kamienieckiego wkroczyły na Mołdawię przed 14 września, czyli w końcu sierpnia lub na początku września. Jednak Marek Plewczyński uważa, że marsz zajął $20 \mathrm{dni}$, a oblężenie Suczawy kolejne trzy tygodnie . $^{8}$ W przekazach kronikarskich jednak nie ma mowy o czasie jaki przebywali Polacy pod Suczawą, a jedyne, szczegółowe informacje o oblężeniu podaje wyłącznie Maciej Stryjkowski:

[...] pod Soczawę stołeczny zamek przystąpili, ale iż próżno szturmowali, też nieprzyjaciela do stoczenia walnej bitwy wywabić nie mogli, bo wojewoda w lesiech się krył, przeto Kamieniecki hetman nie mając co więcej plundrować bo całe dwadzieścia dni rozpuściwszy zagony Wołochy bez oporu burzyli ${ }^{9}$.

Z tego fragmentu wynika, że doszło do oblężenia, ale nie ma informacji o długości jego trwania. Wspomniane 20 dni może być interpretowane jako cały czas przebywania wojsk Kamienieckiego w Mołdawii, a nie spędzony pod Suczawą. Podobny przebieg wydarzeń przedstawia Kazimierz Pułaski ${ }^{10}$. Potwierdzać zdają się to również inne przekazy źródłowe, które wspominają o niecałych trzech tygodniach, ale w różnych fragmentach tekstu i nie odnoszą się do oblężenia. Dlatego wydaje się, że informacja Marka Plewczyńskiego o 3 tygodniach spędzonych pod miastem może pochodzić z błędnej interpretacji źródła.

Dodatkową kwestią, która przemawia przeciw tezie o długim oblężeniu Suczawy jest przygotowanie wojsk polskich. Kamieniecki podjął działania w sierpniu i wrześniu, to jest w końcu lata. Jest mało prawdopodobnym, że spędził tak długi czas na wrogim terytorium. Dodatkowo oddziały polskie nie były przygotowane do prowadzenia długotrwałego oblężenia i nie posiadały potrzebnej do tego artylerii, dlatego nie miało sensu oblężenie twierdzy, której 12 lat wcześniej nie udało się zdobyć, zdecydowanie lepiej

${ }^{6}$ Decjusz, dz. cyt., s. 43-44; M. Stryjkowski, dz. cyt., s. 355.

7 B. Wapowski, dz. cyt., s. 89.

${ }^{8}$ M. Plewczyński, dz. cyt., s. 154.

${ }_{9}^{9}$ M. Stryjkowski, dz. cyt., s. 355.

${ }^{10}$ K. Pułaski, Wojna Zygmunta I. z Bogdanem, s. 121-122. 
do tego przygotowanym oddziałom Jana Olbrachta. Niestety na podstawie obecnej bazy źródłowej trudno wskazać inne, bardziej konkretne wskazówki chronologiczne.

Problemem bezpośrednio powiązanym $\mathrm{z}$ czasem, $\mathrm{w}$ jakim prowadzono kampanię, jest trasa przemarszu wojsk polskich. Wprawdzie przekazy kronikarskie nie podają jej dokładnego przebiegu, ale można tam znaleźć listę miast, jakie zostały przez wyprawę Kamienieckiego zdobyte. Na tej podstawie można dojść do pewnych wniosków. Najpewniej wojska maszerowały przez Pokucie i stamtąd przez Śniatyń, Szepienicę i Czerniowce pod Suczawę. W tej sprawie historycy są zgodni i pokrywa się to z informacjami ze źródeł. Jednak trasa spod Suczawy pod Chocim nie została tak dokładnie określona. Jedyną taką próbę podjął Marek Plewczyński stwierdzając, że najpewniej przebiegała przez Dorohów, Hadir i Chocim ${ }^{11}$. Inni historycy nie podjęli podobnych prób, zgadzając się jednak, że trasa przebiegała przez ziemię szepienicką. $W$ tym momencie należy zaznaczyć pewien błąd jaki powielano w tej sprawie. Zdzisław Spieralski uważał, że była to trasa bezpieczniejsza, gdyż obawiano się powtórzenia sytuacji z 1497 r. Jednak jest to mylne stwierdzenie, gdyż należy pamiętać, że wyprawa Jana Olbrachta nie funkcjonowała jeszcze wtedy w pamięci ludzi jako wielka klęska, a jedynie niepowodzenie. Pogląd o katastrofie militarnej został rozpowszechniony dopiero później ${ }^{12}$. W 1509 r. prawdopodobnie kierowano się tym, że obszary ziemi szepienickiej nie były jeszcze ograbione przez wojska i można tam było łatwiej zdobyć żywność i dokonać dodatkowych zniszczeń. Należy również pamiętać, że armia Mikołaja Kamienieckiego wkraczając do Mołdawii maszerowała zbliżoną trasą do tej jaką w 1497 r. wycofywał się Jan Olbracht. To pokazuje, że nie obawiano się powtórzenia wydarzeń sprzed 12 lat.

Wydaje mi się, że na podstawie przekazów kronikarskich i informacji o ówczesnych szlakach handlowych można podjąć próbę dokładniejszego wytyczenia trasy wojsk Mikołaja Kamienieckiego spod Suczawy. Nie ulega wątpliwości, że najpierw pomaszerowano pod Dorohów, najpewniej przez Botuszany. Stamtąd droga mogła wieść tak jak sugeruje Marek Plewczyński (czyli przez Hadir), ale jest również inna możliwość. W przekazach kronikarskich można znaleźć informację, że oddziały polskie spaliły miejscowość Stepanowce, która znajduje się na wschód od Dorohowa. Mógł to uczynić wysłany podjazd ale również główne wojska, które tam miały możliwość przeprawy przez Prut (niekoniecznie pod Hadirem ${ }^{13}$ ) i stamtąd, wschodnim

11 M. Plewczyński, dz. cyt., s. 156.

12 H. Łowmiański, Polityka Jagiellonów, Poznań 1999, s. 411.

${ }^{13}$ W przekazach kronikarskich miejscowość ta w ogóle nie jest wspominana, natomiast znajdują się tam Tarasowce. Ich położenie odpowiadałoby miejscu potencjalnej przeprawy wojsk polskich na drodze z Dorohowa do Chocimia. 
brzegiem tej rzeki mogły dotrzeć pod Chocim. Pewną wskazówką dotyczącą miejsca przeprawy wojsk Kamienieckiego przez Prut może być miejscowość Tirasovce $^{14}$, którą podaje Bernard Wapowski. Wydaje się prawdopodobne, że może tutaj chodzić o współczesną wioskę Tarasivtsi, znajdującą się na północnym brzegu Prutu. Położona jest dokładnie pomiędzy Dorohowem i Chocimiem. Bardzo możliwe, że Mikołaj Kamieniecki dokonał przeprawy gdzieś w okolicach tej miejscowości. Niestety brakuje dokładniejszych materiałów źródłowych by móc wskazać niebudzącą wątpliwości drogę jaką przebyły wojska polskie. Trasa jaką podałem, od momentu wkroczenia do Mołdawii przez Pokucie, przez Suczawę do Chocimia liczyła około 260 km.

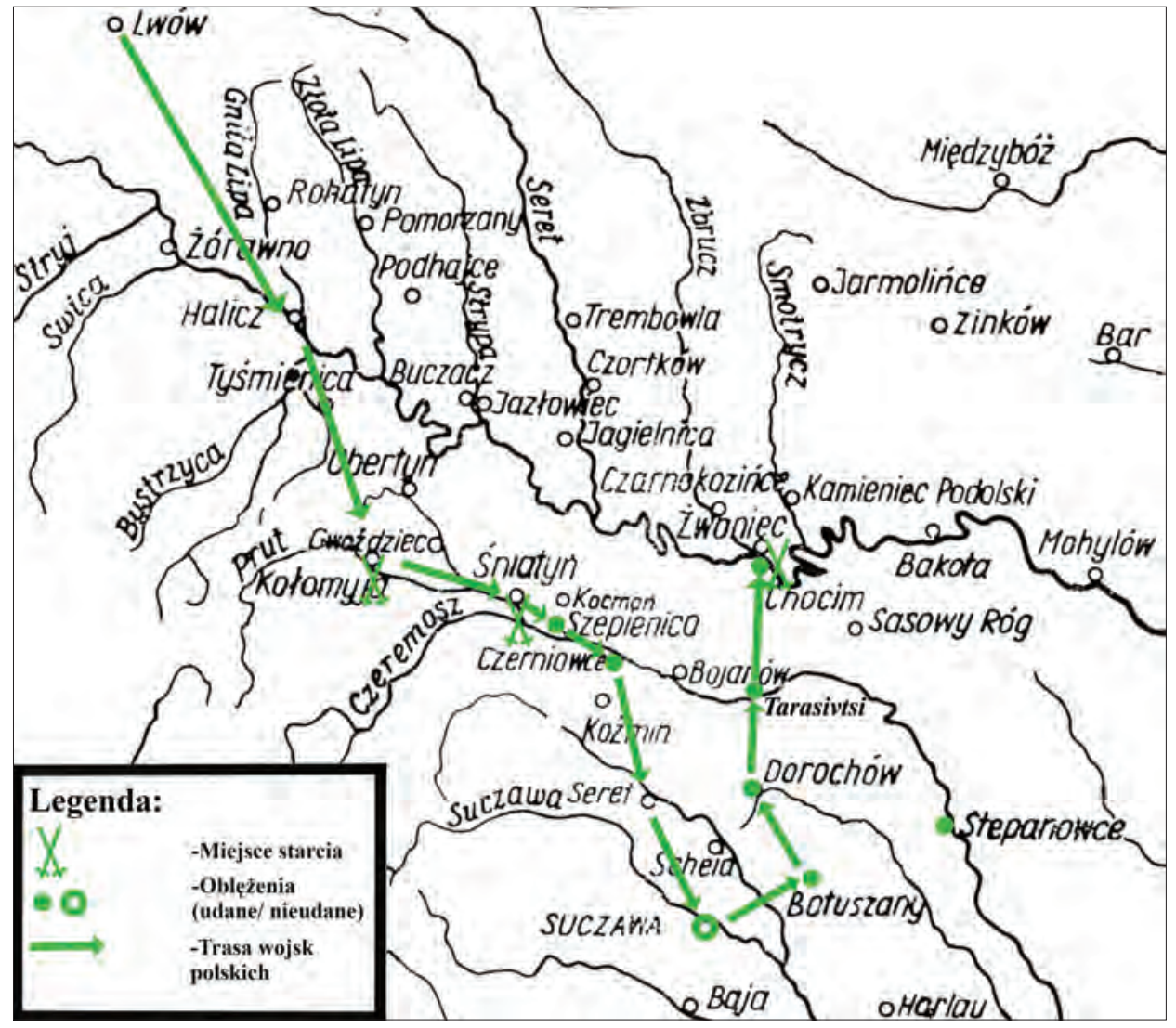

Mapa 1. Działania wojenne armii polskiej w $1509 \mathrm{r}$.

Źró dło: Z. Spieralski, Awantury mołdawskie, Warszawa 1967, s. 40-41

Zaznaczenie przemarszu wojsk - K. Gryglewski

${ }^{14}$ B. Wapowski, $d z$. cyt., s. 89 
Aleksander Bołdyrew w swoim artykule Pochody wojenne wojsk zaciężnych $w$ pierwszej połowie XVI w. (ze szczególnym uwzględnieniem piechoty) wspomina, że oddziały zaciężne były w stanie przemierzać $20 \mathrm{~km}$ dziennie. Uwzględnienie tej liczby dało by możliwość przebycia $260 \mathrm{~km}$, przez armię, wciągu 13 dni. Uwzględniając dni przeznaczone na odpoczynek wydaje się, że trasa z Pokucia, przez Suczawę, do Chocimia była możliwa do przebycia przez armię w ciągu $20 \mathrm{dni}^{15}$.

Ciekawym problemem jest również organizacja i liczebność armii polskiej i mołdawskiej. W przekazach kronikarskich brakuje dokładnych informacji na ten temat. Wiemy tylko, że wojsko Mikołaja Kamienieckiego składało się z pospolitego ruszenia z Podgórza, Rusi i Podola ${ }^{16}$. Drugą część armii tworzyły oddziały zaciężne, obrona potoczna oraz chorągwie nadworne (w tym oddziały pomocnicze z Litwy ${ }^{17}$ ). Oddziały zaciężne szacuje się na 4-5 tysięcy ludzi ${ }^{18}$. Nie mamy konkretnych informacji na temat całkowitej liczebności wojsk miał jakie pod swą komendą Mikołaj Kamieniecki. Marek Plewczyński przypuszcza, że mogły one liczyć nawet 20 tysięcy zbrojnych ${ }^{19}$, jednak $\mathrm{w}$ mojej opinii jest to liczba zawyżona. Udowodnienie tej tezy wymaga oczywiście dokładnej kwerendy w Archiwum Głównym Akt Dawnych, lecz czas przemarszu wydaje się zdecydowanie zbyt krótki na tak liczną armię. Pamiętać należy, że 12 lat wcześniej król Jan Olbracht z armią liczącą około 30-40 tysięcy ludzi (składającej się głównie z pospolitego ruszenia zwołanego z terytorium całego Królestwa Polskiego) maszerował podobną trasą, przez te same terytoria około 4 miesięcy. W 1509 r. armia licząca 20 tysięcy ${ }^{20}$, w tym głównie pospolitego ruszenia, nie mogła w ciągu miesiąca przebyć takich odległości, $w$ tak trudnym terenie. Natomiast gdyby była mniej liczna, z dużym udziałem wojsk zaciężnych, które były lepiej zorganizowane, mogłaby z powodzeniem to uczynić. Dlatego też wydaje mi się, że przeceniano udział oddziałów pospolitego ruszenia. Prawdopodobnie liczebność oddziałów zaciężnych i szlacheckich oscylowała w okolicach 5-10 tysięcy zbrojnych. Dzięki temu udało się Mikołajowi Kamienieckiemu przeprowadzić tak szybkie działania odwetowe na wrogim terytorium.

15 A. Bołdyrew, Pochody wojenne polskich wojsk zaciężnych w pierwszej połowie XVI w. (ze szczególnym uwzględnieniem piechoty), „Piotrkowskie Zeszyty Historyczne” 12/2, 2011, s. 10.

${ }^{16}$ M. Stryjkowski, dz. cyt., Warszawa 1846, s. 355.

17 H. Lulewicz, Litewskie choragwie dworzańskie (dworskie) w wyprawie mołdawskiej 1509 r., [w:] Społeczeństwo i Wojsko, Siedlce 2016, s. 21-31.

${ }^{18}$ Jest to liczba przypuszczalna, gdyż do tej pory udało się z dokumentów archiwalnych oszacować liczebność niektórych oddziałów.

${ }^{19}$ M. Plewczyński, dz. cyt., s. 154.

20 Tamże. 
Osobną kwestią jest liczebność oddziałów hospodara mołdawskiego, które wzięły udział w bitwie nad Dniestrem. Do tej pory w ogóle nie starano się ich oszacowywać ze względu na szczątkowy materiał źródłowy. Pewne informacje podaje Marcin Bielski: „W wojsku Bogdanowym było wszystkiego Rycerstwa Wołoskiego samo prawie czoło, y dwa tysiąca Turków"21. Liczebność oddziałów osmańskich podawana jest również przez Decjusza i Macieja Stryjkowskiego ${ }^{22}$ i nie odbiega od liczby podanej przez Marcina Bielskiego. Na podstawie tego fragmentu można wnioskować, że znaczną część sił hospodara Bogdana III podczas bitwy nad Dniestrem stanowiły tureckie i tatarskie oddziały posiłkowe. Prowadzi to do dalszego wniosku, że siły mołdawskie i ich sojuszników najpewniej liczyły około 4 tysiące ludzi. Obecność Turków i Tatarów jest możliwa. Niewątpliwie ich oddziały były obecne podczas najazdu Bogdana na Podole ${ }^{23}$. Wspomina o tym Zygmunt I w swoim liście. Po powrocie Bogdana III z Podola, część z nich mogła pozostać w Mołdawii i wziąć udział w bitwie nad Dniestrem.

Natomiast wytłumaczeniem niewielkiej liczby wojsk mołdawskich wydaje się sama ich organizacja. Składały się one z „Wielkiej Armii” (pospolite ruszenie) i „Małej Armii” (oddziały zaciężne i nadworne) ${ }^{24}$. Natomiast w kronice Urechiego znajdziemy fragment mówiący, że po powrocie z najazdu na Polskę, hospodar rozpuścił swoją armię i nie spodziewał się najazdu. Niewątpliwie chodziło tutaj o zbrojnych z tzw. „Wielkiej Armii”, którzy służyli czasowo. To działanie hospodara tłumaczyłoby również dlaczego Mikołaj Kamieniecki wkraczając do Mołdawii nie natrafił na większy opór. W wyniku rozpuszczenia „Wielkiej Armii”, która miała charakter tymczasowy, hospodar miał do dyspozycji tylko niewielkie oddziały „Małej Armii”, które były stale utrzymywane oraz osmańskie oddziały posiłkowe. Te oddziały nie mogły być znaczne i liczba 4 tysięcy zbrojnych jest realną siłą jaką hospodar mógł wtedy dysponować. Dodatkową poszlaką jest przebieg bitwy nad Dniestrem, gdzie polskie oddziały zaciężne (około 4-5 tysięcy zbrojnych), wraz z możliwym nielicznym wsparciem pospolitego ruszenia ${ }^{25}$, otoczyły

${ }^{21}$ M. Bielski, dz. cyt., s. 122-123.

22 Decjusz, dz. cyt., s. 43-44; M. Stryjkowski, dz. cyt., s. 356.

${ }^{23}$ Acta Tomiciana; Epistole. Legationes. Responsa. Actiones. Res Geste; Serenissimi Principis Sigismundi, Ejus Nominis Primi, Regis Polonie, Magni Ducis Lithuanie, Russie, Prussie, Masovie Domini. Quarum Primus Hic Tomus Est, Poznań 1852, Appendix, 23, s. 33-34.

${ }^{24}$ Z. Spieralski, Awantury Mołdawskie, s. 44.

${ }^{25}$ W przekazach kronikarskich wspomina się, że przed bitwą nad Dniestrem, oddziały polskie były podzielone przez rzekę. Pospolite ruszenie miało być już na polskim brzegu, natomiast zaciężni szykowali się do przeprawy. Zrozumiałym jest, że to właśnie tym ostatnim przypisuje się największy wkład w zwycięstwo, jednak przekazy kronikarskie wspominają o przygotowaniach do bitwy, podczas których można się domyślać, że oddziały polskie na mołdawskim brzegu mogły zostać wzmocnione przez jakąś grupę pospolitego ruszenia. 
znaczą część wojsk hospodara. Gdyby wojska mołdawskie były znacznie liczniejsze niż oddziały polskie lub posiadali siły porównywalne do polskich, to taki manewr byłby bardzo trudny do zrealizowania. Pamiętać również należy, że wojska Kamienieckiego były rozdzielone rzeką. Gdyby Mołdawianie posiadali duże siły, nie ponieśliby tak znacznej porażki a być może sami by zwyciężyli, korzystając ze sprzyjających okoliczności. Właśnie poprzez uznanie małej liczebności wojsk mołdawskich opisany przez kronikarzy przebieg bitwy nad Dniestrem staje się prawdopodobny. Jest to równocześnie kolejny argument za niewielką liczebnością wojsk polskich. Bitwa nad Dniestrem najpewniej była niewielkim starciem, w którym brało udział co najwyżej kilka lub kilkanaście tysięcy zbrojnych.

Warto również zaznaczyć pewien problem, który do tej pory w historiografii nie wybrzmiał. Chodzi tutaj o polityczny wymiar kampanii Mikołaja Kamienieckiego z 1509 r. Warto pamiętać, że polska dyplomacja była bardzo aktywna w sprawie Mołdawii i regularnie dochodziło do kontaktów ze stroną węgierską, które miały na celu rozwiązanie problemu Pokucia i mariażu Bogdana III i Elżbiety Jagiellonki. Wysłannicy Władysława Jagiellończyka starali się mediować między zwaśnionymi stronami, a król Zygmunt I regularnie relacjonował o sytuacji na Podolu i Pokuciu. Jest to bardzo ciekawa sytuacja, gdy w kontaktach dyplomatycznych między dwoma państwami obecne są interesy trzeciego. Wydaje się, że można przyjąć, iż Polska uznawała zwierzchnictwo Węgier nad Mołdawią i starała się unikać samodzielnych działań, które mogły doprowadzić do podobnej sytuacji co w 1497 r., kiedy przeciw wyprawie Jana Olbrachta, który działał bez uzgodnienia z innymi państwami w regionie, stanęły również oddziały węgierskie, a król Władysław Jagiellończyk groził, że sam wkroczy tam z armią. W 1509 r. widać znaczącą zmianę. Polska stara się oficjalnie uzgadniać z Węgrami swoje posunięcia. Natomiast w przekazie propagandowym ukazywano działania Bogdana, jako sprzeczne z powinnościami wasala, za którego Polska chciała go uznawać. Tym też należy tłumaczyć brutalność metod użytych podczas działań zbrojnych. Najlepszym świadectwem takiego charakteru wojny są słowa Decjusza o hospodarze Bogdanie: „[...] wbrew prawu międzynarodowemu, zrzucił brzemię zależności, złamał przymierze i wkroczył na Ruś i Podole, gdzie napełnia wszystko rzezią i pożogą"26. Doskonale ukazują one stosunek strony polskiej do mołdawskiej. Konflikt wewnętrzny charakteryzował się zupełnie innymi regułami. Każde wystąpienie przeciw seniorowi było zdradą i trzeba było je przykładnie ukarać.

${ }^{26}$ Decjusz, dz. cyt., s. 41. 
Dodatkową przyczyną szybkiej pacyfikacji wystąpienia Bogdana III, były jego stosunki z Wielkim Księstwem Moskiewskim. Iwan III kilkukrotnie starał się skłonić hospodara do ataku na Polskę, w ramach dywersji dla walk na Litwie. Polska niewątpliwie zdawała sobie z tego sprawę. Równocześnie sam hospodar Bogdan ingerował dyplomatycznie w próby zawarcia sojuszu między Polską a Chanatem Krymskim. Sojusz taki pozbawiłby Moskwę ważnego sojusznika i mógłby stanowić dla niej zagrożenie. Równocześnie ustabilizowanie sytuacji na południowo-wschodnich obszarach monarchii jagiellońskiej nie byłoby na rękę Mołdawii, która mogła się czuć zagrożona. W 1508 r. Bogdan III pisał do Chana Menli Gireja ${ }^{27}$, żeby nie zawierał układów z Polską. List ten został przekazany stronie jagiellońskiej prawdopodobnie przez samych Tatarów. W takiej sytuacji konflikt w Mołdawii stawał się ważny w kontekście o wiele istotniejszych dla strony polsko-litewskiej walk na Litwie. Pacyfikacja Mołdawii była niewątpliwie próbą ukarania Bogdana III za jego ingerencję, stanowiąc jednocześnie próbę zabezpieczenia południowych granic Królestwa w obliczu zbliżającej się wojny z Wielkim Księstwem Moskiewskim.

Do tej pory kampania mołdawska Mikołaja Kamienieckiego z 1509 r. nie była obiektem szczególnego zainteresowania historyków. W niniejszej pracy starałem się przedstawić kilka problemów, na jakie do tej pory nie starano się odpowiedzieć, a po dokładnym przeanalizowaniu przekazów źródłowych, można dojść do pewnych wniosków. Takimi kwestiami są: liczebność wojsk polskich i mołdawskich, czas trwania wyprawy Mikołaja Kamienieckiego oraz trasa przemarszu wojsk. Niewątpliwie ta praca nie wyczerpuje tematu i istnieją możliwości i źródła do lepszego poznania omawianych wydarzeń.

${ }^{27}$ K. Puławski, Stosunki z Mendli-Girejem chanem Tatarów perekopskich (1469-1515), [w:] Akta i Listy, Kraków, Warszawa 1881, s. 100-101. 


\section{BIBLIOGRAFIA}

\section{Źródła drukowane}

Acta Tomiciana; Epistole. Legationes. Responsa. Actiones. Res Geste; Serenissimi Principis Sigismundi, Ejus Nominis Primi, Regis Polonie, Magni Ducis Lithuanie, Russie, Prussie, Masovie Domini. Quarum Primus Hic Tomus Est, Poznań 1852.

Bielski M., Kronika polska Marcina Bielskiego, cz. 5, Warszawa 1830.

Decjusz, Księga o czasach Króla Zygmunta, Warszawa 1960.

Stryjkowski M., Kronika polska, litewska, żmudzka i wszystkiej Rusi Macieja Stryjkowskiego, t. 2, Warszawa 1846.

Ureche G., Letopisetul Tarii Moldovei de cand sau descalecat tara, t. I, https://archive.org/ details/LetopisetulTariiMoldoveiDeCandS-auDescalecatTara/page/n123/mode/2up, (dostęp: 18.12.2019).

Wapowski B., Kronika Bernarda Wapowskiego z Radochoniec kantora katedr. krakowskiego: część ostatnia czasy podługoszowskie obejmująca (1480-1535), Kraków 1874.

\section{Opracowania}

Bołdyrew A., Horyzont geograficzny żołnierzy zaciężnych w Polsce ostatnich Jagiellonów. Przyczynek do badań nad mobilnościq grupy zawodowej, [w:] Studia z dziejów wojskowości, t. 6, Białystok 2017.

Bołdyrew A., Piechota zaciężna w Polsce w pierwszej połowie XVI wieku, Warszawa 2011.

Bołdyrew A., Pochody wojenne polskich wojsk zaciężnych w pierwszej połowie XVI w. (ze szczególnym uwzględnieniem piechoty), „Piotrkowskie Zeszyty Historyczne” 2011, nr 12, cz. 2, s. 9-26.

Charewiczowa Ł., Handel Lwowa z Multanami w wiekach średnich, Lwów 1924.

Czamańska I., Mołdawia i Wołoszczyzna wobec Polski, Węgier i Turcji w XIV i XV wieku, Poznań 1996.

Gryglewski K., Polskie wyprawy zbrojne na Mołdawię w latach 1497, 1509, 1531. Analiza porównawcza, Łódź 2019. Praca licencjacka napisana pod kierunkiem prof. nadzw. dr. hab. Tadeusza Grabarczyka, w Katedrze Historii Średniowiecznej, na Wydziale Historyczno-Filozoficznym UŁ.

Lubomirski T., Trzy rozdziały z historyi skarbowości w Polsce 1507-1532, Kraków 1868.

Lulewicz H., Litewskie choragwie dworzańskie (dworskie) w wyprawie mołdawskiej 1509 r., [w:] Społeczeństwo polskie i wojsko, Siedlce 2016.

Łowmiański H., Polityka Jagiellonów, Poznań 1999.

Niemczyk K., Chodeccy a wyprawa mołdawska z 1509, „Balcanica Posnanensia” 2017, t. 24, Poznań 2017.

Niemczyk K., Mołdawia Bogdana III Ślepego w polityce Aleksandra Jagiellończyka, [w:] Jagiellonowie i ich świat: Dynastia królewska w drugiej połowie XVi w XVI wieku, red. B. Czwojdrak, J. Sperka, P. Węcowski, Kraków 2015. 
Plewczyński M., Mikołaj Kamieniecki, [w:] Poczet hetmanów Rzeczpospolitej: Hetmani koronni, red. M. Nagielski, Warszawa 2005.

Plewczyński M., Wojny i wojskowość polska w XVI wieku: lata 1500-1548, Zabrze 2011.

Puławski K., Stosunki z Mendli-Girejem chanem Tatarów perekopskich (1469-1515), [w:] Akta i Listy, Kraków-Warszawa 1881.

Puławski K., Wojna Zygmunta I. z Bohdanem wojewodq mołdawskim w 1509, [w:] Szkice i poszukiwania historyczne, Kraków 1887.

Spieralski Z., Awantury mołdawskie, Warszawa 1967.

Spieralski Z., Mikołaj Kamieniecki, [w:] Polski Słownik Biograficzny, t. 11, Wrocław-WarszawaKraków 1964-1965.

\section{Materiały kartograficzne}

Spieralski Z., Awantury Mołdawskie, Warszawa 1967, s. 40-41.

Krzysztof Gryglewski

\section{REMARKS ON THE MOLDOVIAN CAMPAIGN OF MIKOŁAJ KAMIENIECKI IN 1509}

$\mathrm{N}$ icolas Kamienieckis campaign in Moldavia is poorly known and few historians were interested in it. The purpose of this article is to analyse available historical sources about this campaign. Mainly areas of interest are duration of campaign, the way of polish troops in Moldavia and political background of this events. Available historical sources enable to reveal new facts and propose new conclusions about polish campaign in 1509.

Keywords: Bogdan III the One-Eyed, Sigismund I the Old, Principality of Moldavia 1509 polish-moldavian war, Nicholas Kamieniecki. 